\title{
How many common reptile species are fire specialists? A replicated natural experiment highlights the predictive weakness of a fire succession model
}

\author{
Don A Driscoll ${ }^{a, *}$, Meredith K Henderson ${ }^{b}$ \\ ${ }^{a}$ School of Biological Sciences, Flinders University. GPO Box 2100, Adelaide SA 5001, Australia \\ bscience and Conservation, Department for Environment and Heritage, C/- Botanic Gardens of Adelaide, North Terrace, Adelaide SA 5000, \\ Australia
}

\section{A R T I C L E I N F O}

\section{Article history:}

Received 9 July 2007

Received in revised form

14 October 2007

Accepted 21 October 2007

Available online 11 December 2007

Keywords:

Fire management

Habitat accommodation model

Lizard

Australian mallee Eucalyptus

Bushfire

Prescribed burning

\begin{abstract}
A B S T R A C T
Species with strong preferences for early or late successional stages after fire may be extinction prone under current fire regimes. However, the extent of specialisation to time since fire is poorly understood, and, for reptiles, succession models for predicting responses are in the development phase. In this study we tested predictions of a reptile succession model, and identified species that may be fire specialists. Reptiles were sampled in five burnt and unburnt mallee Eucalyptus woodlands, Australia. Two, $400 \mathrm{~m}$ transects within each burn treatment were sampled using 11 pairs of pitfall-traps that were opened for five weeks over two summers. A habitat accommodation model of succession that was previously developed for mallee reptiles correctly predicted the observed responses of three of 16 common reptile species. A further four species showed non-significant trends in the predicted direction. However, eight other species showed unexpected responses. One species showed a strong interaction between burn age and location, requiring a two-dimensional successional model in contrast with the usual linear models explaining reptile responses to fire. One third of common species were not affected by fire and so may not have increased risks of extinction due to the fire suppression/incineration cycle. However, approximately half to two-thirds of common reptiles did have a fire response, so the risk of deterministic extinction in small fragments may be substantial. Further model development is needed to better predict fire responses and to assist the design of fire mosaics that can accommodate early and late successional fire specialists.
\end{abstract}

(C) 2007 Elsevier Ltd. All rights reserved.

\section{Introduction}

Species that have specialist habitat requirements may be particularly vulnerable to extinction in fragmented landscapes (Fischer and Stocklin, 1997; Kolb and Diekmann, 2005). Specialising on a particular post-fire successional stage is one mechanism that may lead to a heightened risk of extinction.
A single fire could burn the entire remnant, removing any long-unburnt habitat and placing late-successional specialists at risk of local extinction (Gandhi et al., 2001; Woinarski et al., 2004). However, fire suppression is common in many human-dominated landscapes, and it may be the early successional species that are most vulnerable to extinction in small remnants (Gibb and Hochuli, 2002; Hobbs, 2003). Cycles

\footnotetext{
* Corresponding author: Address: Fenner School of Environment and Society, Australian National University, W.K Hancock Building (43), Biology Place, Canberra ACT 0200, Australia. Tel.: +61 261258130.

E-mail addresses: don.driscoll@anu.edu.au (D.A. Driscoll), henderson.meredith@saugov.sa.gov.au (M.K. Henderson). 0006-3207/\$ - see front matter @ 2007 Elsevier Ltd. All rights reserved. doi:10.1016/j.biocon.2007.10.016
} 
of fire exclusion for decades followed by complete incineration of a patch have the potential to eliminate early and late-successional species. To understand the magnitude of the threat to wildlife of the fire exclusion/incineration cycle, the number of fire specialists, species dependent on a particular post-fire period, needs to be established.

General patterns of how fauna respond during post-fire succession have been explored (Andersen, 1991; Fox et al., 2003; Friend and Wayne, 2003). For reptiles, most authors report patterns consistent with Fox's (1982) habitat accommodation model of succession, where the reptile community follows a predictable sequence based on the recovery of vegetation structure after fire (Mushinsky, 1985, 1992; Greenberg et al., 1994; Taylor and Fox, 2001a, b; Letnic et al., 2004). A detailed habitat accommodation model for reptiles was described by Caughley (1985) using a fire chronosequence in mallee Eucalyptus woodlands, Australia. Caughley (1985) identified three distinct fire responses (Fig. 1), showing that burrowing species are most common in recently burned sites, species that shelter in Triodia, a prickly clumping grass (Rice and Westoby, 1999), are most abundant after six years when Triodia recovers, but the litter dwelling species do not peak until 25 years after fire, when the leaf litter layer is well established. The responses reported by Caughley and others (Cogger, 1984; Woinarski, 1989; Schlesinger et al., 1997) imply that many reptile species may be fire specialists in Australian mallee communities.

Although there is ample evidence that fire can have a large effect on reptile community composition (Bradstock and Cohn 2002), there is growing evidence that fire has only a secondary influence compared with other processes (Cavitt, 2000; Bamford and Roberts, 2003). For example, in tropical woodlands of northern Australia, Trainor and Woinarski (1994) found that a moisture gradient had the dominant effect on reptile community composition, not fire. For reptiles in Australia's arid and semi-arid areas, there is a strong distinction between communities on sandy soils with Triodia species compared with communities on clay soils without Triodia (Cogger, 1984; Pianka, 1996; Driscoll, 2004). Furthermore, arid-zone reptiles can show strong responses to the amount of rainfall (James, 1991) or grazing (James, 2003; Driscoll, 2004). It is therefore uncertain whether a majority of reptile

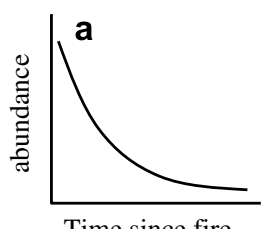

Time since fire

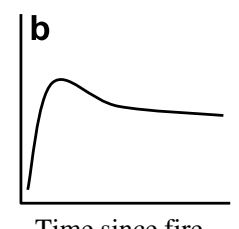

Time since fire

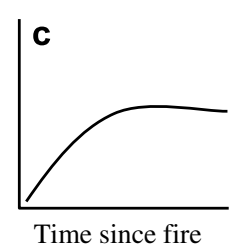

Fig. 1 - Three reptile succession trajectories after fire, based on Caughley's (1985) observed responses. (a) burrowing species that forage in open areas are most abundant after a fire then decline; (b) Triodia spp. specialist species decline after the fire but recover over approximately six years as Triodia re-grows and (c) leaf-litter specialists recover over approximately 25 years because leaf litter is slow to accumulate after fire. species should show strong responses to fire, or whether fire effects will be over-ridden by other local ecological processes.

In this study, we use a large-scale replicated natural experiment to test predictions about the abundance of species in early and late successional habitat that arise from Caughley's (1985) succession model. Replicated studies of animal responses to fire regimes are a major research gap (Whelan et al., 2002) and remain a research priority in fire-prone communities (Greenberg, 2000; Bradstock and Cohn, 2002; Parr and Chown, 2003; Bury, 2004). We also aim to ascertain the proportion of reptile species that are fire specialists with a preference for early or late successional habitat. These species may be vulnerable to decline in the absence of appropriate fire regimes.

\section{Methods}

\subsection{Study area}

Mallee communities are open woodlands with low, multistemmed Eucalyptus species (Specht, 1971). Mallee vegetation covered 383,000 square kilometers of Australia but 35\% of that has been cleared (Australian Native Vegetation Assessment, 2001). On the Eyre Peninsula, South Australia, 56\% of the landscape has been cleared, mostly before 1939, leaving a small number of very large mallee reserves, and many small remnants (Australian Native Vegetation Assessment, 2001; State of the Environment Report, 2003) (Fig. 2).

Mallee on the Eyre Peninsula is dominated by Eucalyptus incrassata, E. brachycalyx, E. socialis and other Eucalyptus species, with a shrubby understorey including Melaleuca uncinata, Baeckea crassifolia, Phebalium bullatum, Callitris verrucosa and spinifex (Triodia irritans), a sharply spined clumping grass (Specht, 1971; Robinson and Heard, 1985). The mallee regions of the Eyre Peninsula include extensive regions of parabolic and longitudinal dunes overlying solid limestone calcrete (Twidale and Campbell, 1985). There is a mediterranean climate with annual rainfall ranging from approximately $300 \mathrm{~mm}$ near Pinkawillinie to $400 \mathrm{~mm}$ near Hincks Conservation Parks (Schwerdtfeger, 1985). Although mallee is extremely flammable, it is regarded as frequently burnt if there is more than one fire in fifteen years (Bradstock and Cohn, 2002).

\subsection{Survey design}

At each of five locations, two sites were placed in a recently burnt area and two sites in an adjacent long-unburnt area. All burnt areas were the result of hot wildfires ignited by lightning or farm machinery. The long unburnt sites were all greater than 18 years old at the beginning of the study, and the recently burnt sites were between three and seven years old (Table 1). Caughley's (1985) model makes predictions about the relative abundance of species with particular ecological traits in early and late successional habitat. Using replicate fires in two age categories it is therefore possible to statistically test the model predictions.

Each of the four sites was sampled using 11 pitfall trap stations spaced at $40 \mathrm{~m}$ intervals along a $400 \mathrm{~m}$ transect. Sites were positioned so that they were at least $200 \mathrm{~m}$ from a fire 


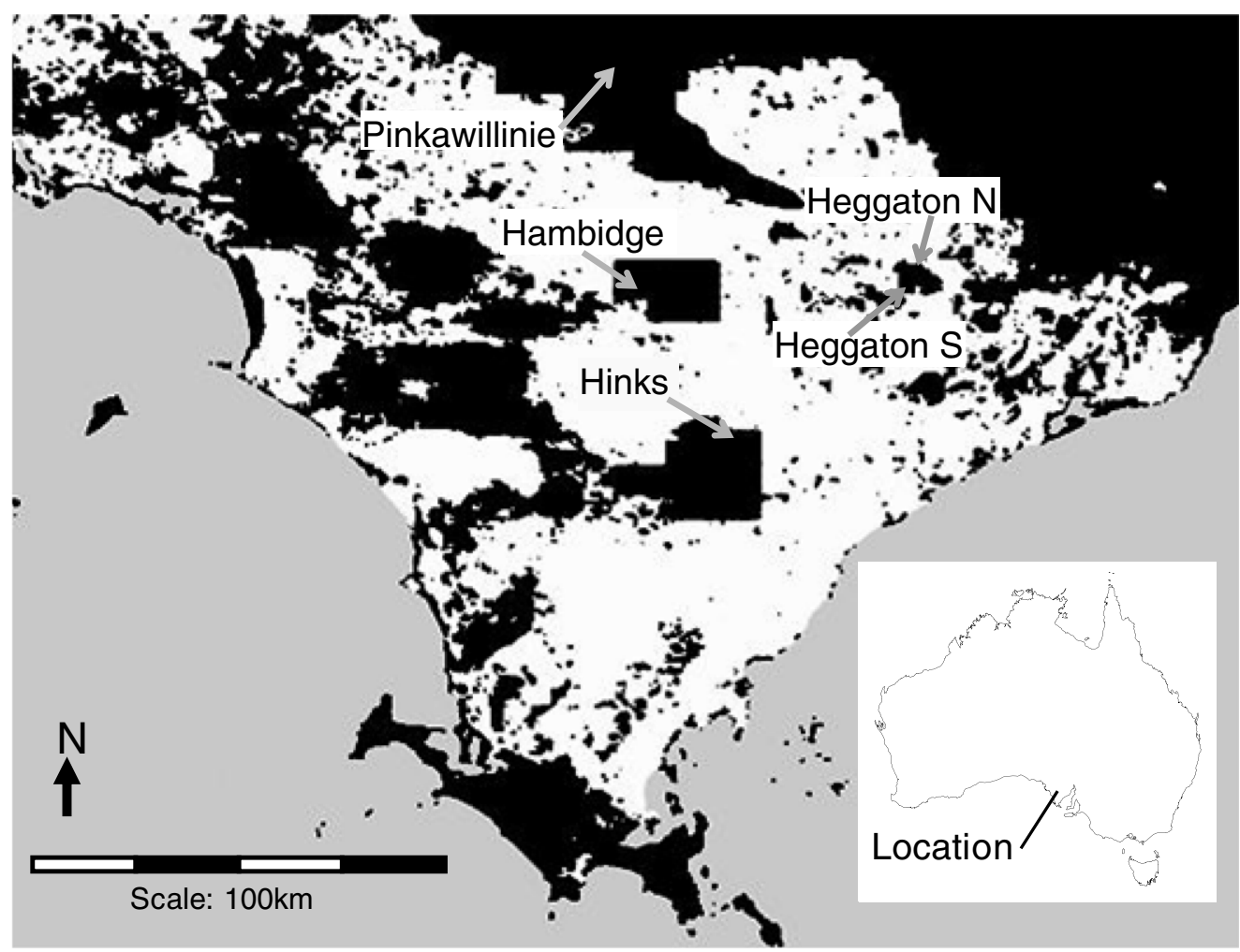

Fig. 2 - Remnant vegetation (black) and study areas on the Eyre Peninsula, South Australia. Five wildfires and adjacent long unburned sites were the focus of the study. (Vegetation mapping from Australian Native Vegetation Assessment, 2001).

Table 1 - Site details, indicating the year each site was last burnt and the age of the burn at the beginning of the study

\begin{tabular}{|c|c|c|c|c|c|c|}
\hline Location (location code) & Site & Latitude & Longitude & Burn category & Year last burnt & Burn age \\
\hline \multirow[t]{4}{*}{ Hambidge (A) } & 1 & $33^{\circ} 26^{\prime} 29^{\prime \prime} \mathrm{S}$ & $135^{\circ} 52^{\prime} 3 " \mathrm{E}$ & Burn & January 2000 & 4 \\
\hline & 2 & $33^{\circ} 25^{\prime} 42^{\prime \prime S}$ & $135^{\circ} 50^{\prime} 45^{\prime \prime} \mathrm{E}$ & Burn & January 2000 & 4 \\
\hline & 3 & $33^{\circ} 27^{\prime} 45^{\prime \prime} \mathrm{S}$ & $135^{\circ} 51^{\prime} 55^{\prime \prime} \mathrm{E}$ & Unburnt & October 1965 & 39 \\
\hline & 4 & $33^{\circ} 25^{\prime} 44^{\prime \prime} \mathrm{S}$ & 135॰49’14"E & Unburnt & October 1965 & 39 \\
\hline \multirow[t]{4}{*}{ Hincks (I) } & 1 & $33^{\circ} 45^{\prime} 49^{\prime \prime} \mathrm{S}$ & $136^{\circ} 4^{\prime} 48^{\prime \prime} \mathrm{E}$ & Burn & January 1999 & 5 \\
\hline & 2 & $33^{\circ} 47^{\prime} 26^{\prime \prime} \mathrm{S}$ & $136^{\circ} 8^{\prime} 28^{\prime \prime} \mathrm{E}$ & Burn & January 1999 & 5 \\
\hline & 3 & $33^{\circ} 45^{\prime} 48^{\prime \prime} \mathrm{S}$ & $136^{\circ} 3^{\prime} 34^{\prime \prime} \mathrm{E}$ & Unburnt & December 1977 & 27 \\
\hline & 4 & $33^{\circ} 48^{\prime} 35^{\prime \prime} \mathrm{S}$ & $136^{\circ} 8^{\prime} 44^{\prime \prime} \mathrm{E}$ & Unburnt & December 1977 & 27 \\
\hline \multirow[t]{4}{*}{ Heggaton North $(\mathrm{N})$} & 1 & $33^{\circ} 22^{\prime} 7 ” S$ & $136^{\circ} 32^{\prime} 22^{\prime \prime} \mathrm{E}$ & Burn & November 1997 & 7 \\
\hline & 2 & $33^{\circ} 21^{\prime} 23^{\prime \prime} \mathrm{S}$ & $136^{\circ} 32^{\prime} 35^{\prime \prime} \mathrm{E}$ & Burn & November 1997 & 7 \\
\hline & 3 & $33^{\circ} 22^{\prime} 9 " \mathrm{~S}$ & $136^{\circ} 31^{\prime} 40^{\prime \prime} \mathrm{E}$ & Unburnt & Long unburnt & $>30$ \\
\hline & 4 & $33^{\circ} 21^{\prime} 52^{\prime \prime} \mathrm{S}$ & 136³2’1"E & Unburnt & Long unburnt & $>30$ \\
\hline \multirow[t]{4}{*}{ Heggaton South (S) } & 1 & $33^{\circ} 24^{\prime} 51^{\prime \prime} \mathrm{S}$ & $136^{\circ} 31^{\prime} 22^{\prime \prime E}$ & Burn & January 2001 & 3 \\
\hline & 2 & $33^{\circ} 24^{\prime} 54^{\prime \prime} \mathrm{S}$ & $136^{\circ} 31^{\prime} 40^{\prime \prime} \mathrm{E}$ & Burn & January 2001 & 3 \\
\hline & 3 & $33^{\circ} 24^{\prime} 34^{\prime \prime} \mathrm{S}$ & 136³1'2"E & Unburnt & Long unburnt & $>30$ \\
\hline & 4 & $33^{\circ} 24^{\prime} 39^{\prime \prime} \mathrm{S}$ & 13631'39"E & Unburnt & Long unburnt & $>30$ \\
\hline \multirow[t]{4}{*}{ Pinkawillinie (P) } & 1 & $32^{\circ} 54^{\prime} 11^{\prime \prime} \mathrm{S}$ & $135^{\circ} 52^{\prime} 30^{\prime \prime} \mathrm{E}$ & Burn & October 2001 & 3 \\
\hline & 2 & $32^{\circ} 54^{\prime} 30^{\prime \prime} \mathrm{S}$ & $135^{\circ} 52^{\prime} 32^{\prime \prime} \mathrm{E}$ & Burn & October 2001 & 3 \\
\hline & 3 & $32^{\circ} 54^{\prime} 47^{\prime \prime} \mathrm{s}$ & $135^{\circ} 51^{\prime} 53^{\prime \prime} \mathrm{E}$ & Unburnt & 1986 & 18 \\
\hline & 4 & $32^{\circ} 54^{\prime} 51^{\prime \prime} \mathrm{S}$ & $135^{\circ} 52^{\prime} 14^{\prime \prime} \mathrm{E}$ & Unburnt & 1986 & 18 \\
\hline
\end{tabular}

Where records are available, the "burn" sites were previously burnt in the same fire as the "unburnt" sites.

or woodland edge, and oriented perpendicularly to duneswale direction where this was evident. The distance between sites within a location depended on the size and position of the recent fire and varied from $330 \mathrm{~m}$ at Heggaton South, which was a very small fire, up to $8 \mathrm{~km}$ at Hincks. Sites were selected so that each sampled similar soil types and dune for- mations within locations, and were $400 \mathrm{~m}$ long to ensure a range of dune and swale habitat was sampled. Each pitfall trap station consisted of two 20 liter buckets buried to their rim and $10 \mathrm{~m}$ apart, with $20 \mathrm{~m}$ of black PVC plastic drift fence linking the two buckets and extending $5 \mathrm{~m}$ either side. All sites were surveyed for seven consecutive nights in December 
2004, January, February, and December 2005, and February 2006. A wildfire burnt the Pinkawillinie "unburnt" sites after the December sample in 2005, so February 2006 data are excluded for that location. All reptiles that were captured were identified, individually or batch marked to indicate month of capture only, and released. Occasional dangerous snakes were released without marking. Bearded dragons (genus Pogona) could not be reliably identified in the field and unpublished mtDNA studies suggest there may be two allopatric taxa in our study area (Jane Melville, Museum Victoria, personal communication). We therefore combine all Pogona records, with any differences between possible species likely to appear as a location effect.

\subsection{Analysis}

An initial analysis included an ANOVA that took into account the nested structure of the two years of data. A range of significant Year main effects and interactions were observed, and in all cases the effect was to reduce abundance in the second year. The second year of sampling did not include any very hot $\left(>45^{\circ} \mathrm{C}\right)$ days, which led to lower capture rates, meaning that any real changes in abundance between years could not be detected. For this reason, the two years of data were pooled for all analyses. Data analysed therefore are counts of animals from each site, summed across the five sample periods.

Species with abundance equal to the number of sites (20) were analyzed (Driscoll, 2004). One exception to this rule of thumb was made for a species with 19 individuals all from one location and an obvious response to the fire age. The abundance of these common reptile species was log +1 transformed before analysis, and this ensured the residuals were approximately evenly distributed with respect to the fitted values (Quinn and Keough, 2002). The analysis included factors Burn (recently burnt vs long unburnt), Location (the five separate locations) and Burn $\times$ Location. Because the two transects within each burn treatment and site could be construed as pseudo-replicates of the burn treatment, transects were regarded as nested within burn. Therefore, the denominator in the $F$-test for burn effect was the Burn $\times$ Location level with $4^{\circ}$ of freedom, and not the overall residual. We report results of statistical tests where $P<0.1$.

Non-metric multidimensional scaling (MDS) with a BrayCurtis distance matrix was used to obtain an overview of community divergence among locations and burn treatments. Presence/absence data were used for this analysis. Multidimensional scaling was completed using functions initMDS and isoMDS of $\mathrm{R}$ version 2.0.1 (Venables and Ripley, 2002; R Development Core Team, 2004). Multiple starts of the multidimensional scaling procedure were undertaken to avoid being trapped in local minima. New starts were continued until the stress had not been reduced for 100 successive iterations. The maximum iterations within isoMDS was 200 , and convergence tolerance $10^{-7}$. Procrustes rotation was performed with postMDS so that most of the variation was captured in axis 1 with R package vegan (Oksanen et al., 2006). ANOSIM (Clarke, 1993), comparing the within and between group Bray-Curtis distances was used to test for differences between locations, and between burn treatments within locations. One thousand permutations of the data were used for calculating the probability of the real data compared with randomized data.

To test the model of reptile succession in mallee (Fig. 1), we used the available literature on habitat preferences to predict the successional response category of common reptile species. The predicted response was compared against the observed response that emerged from the ANOVA analysis.

Table 2 - Analysis of variance results for the 16 common reptile species, showing main effects for Burn and Location, and the interaction between Burn and Location

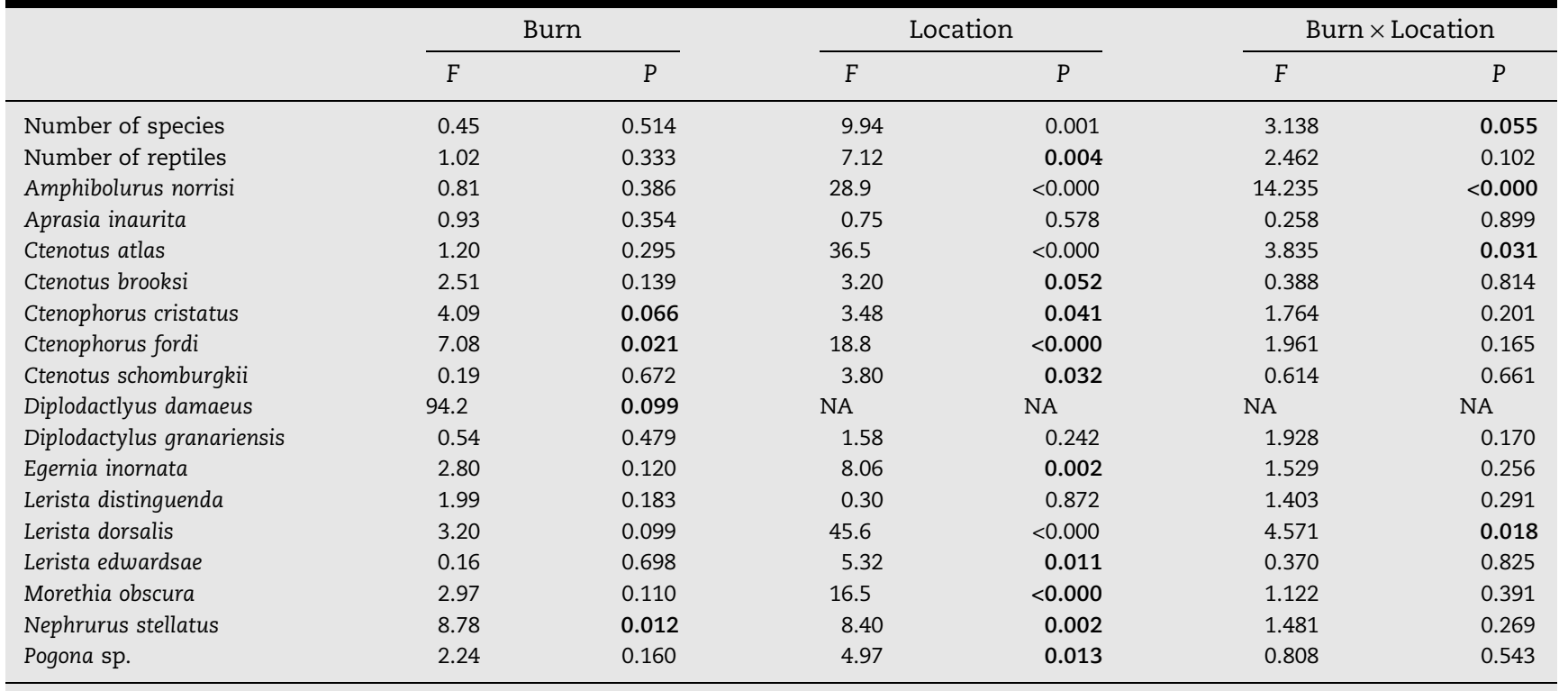

Degrees of freedom 1 and 4 in all cases except Diplodactylus damaeus which only occurred at one location $(D F=1,2)$. Significant $(P<0.1)$ main effects when there is not a significant interaction, and significant interactions in bold type. 


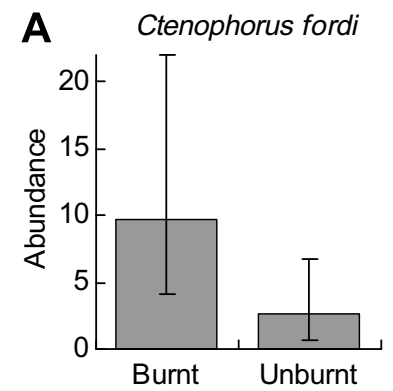

C Diplodactylus damaeus

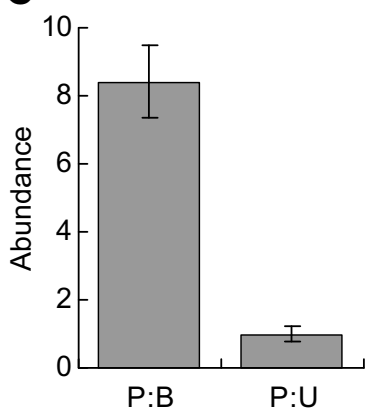

B Nephrurus stellatus

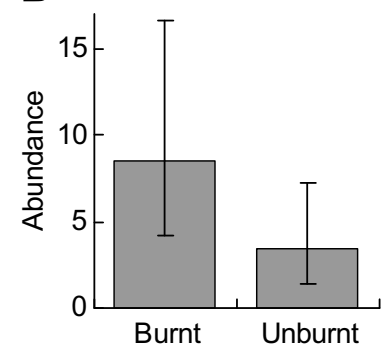

D Ctenophorus cristatus

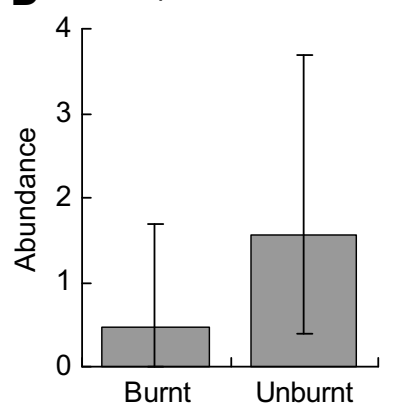

Fig. 3 - Three reptile species had higher mean abundance in recently burnt (B) sites, and one species had higher mean abundance in long unburnt (U) sites. Diplodactylus damaeus was only captured at Pinkawillinie (P). Error bars indicate 95\% confidence limits.

A

Amphibolurus norrisi

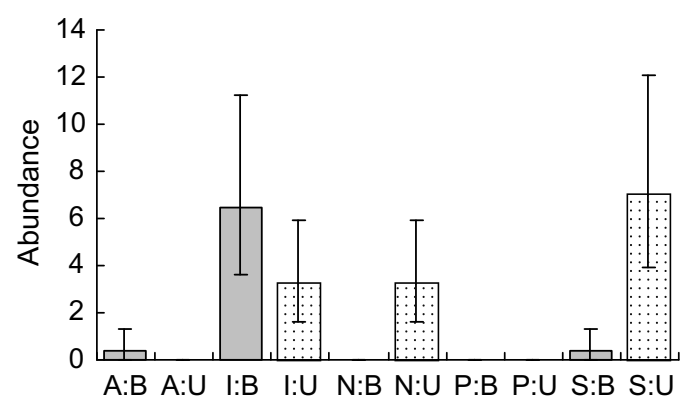

C

Lerista dorsalis

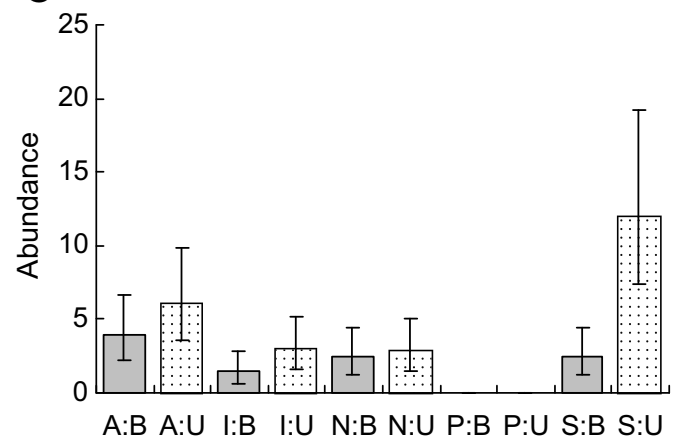

\section{Results}

In total 1585 reptiles were captured, including 42 reptile species and 15 species with 20 or more records. One additional species with 19 records from one location (Diplodactylus damaeus) was included in the analysis, making 16 common species that were analysed.

Four of the 16 common species showed burn effects with $P<0.1$ (Table 2, Fig. 3). The agamid, Ctenophorus fordi, and the geckos Nephrurus stellatus and Diplodactylus damaeus were all more abundant on recently burnt sites, although the latter species was only captured at Pinkawillinie (Fig. 3A-C). The opposite pattern was shown by the agamid Ctenophorus cristatus (Fig. 3D).

Three of the 16 common species showed an interaction between location and burn (Table 2). The agamid Amphibolurus norrisi was more abundant on burnt sites at Hincks, but was more abundant on unburnt sites at Heggaton North and Heggaton South (Fig. 4A), a pattern that is not consistent with time since fire. In contrast, the skink Ctenotus atlas was less abundant in the burnt sites at Heggaton South and Pinkawillinie, which were the most recently burnt sites (burnt 2001, Table 1), but showed the opposite pattern at Heggaton North and Hincks, which were burnt two to three years earlier than Heggaton South and Pinkawillinie (Table 1, Fig. 4B). This pattern is consistent with the spinifex specialist model, where populations are expected to recover as spinifex recovers after about six years (Fig. 1B). A second

B

Ctenotus atlas

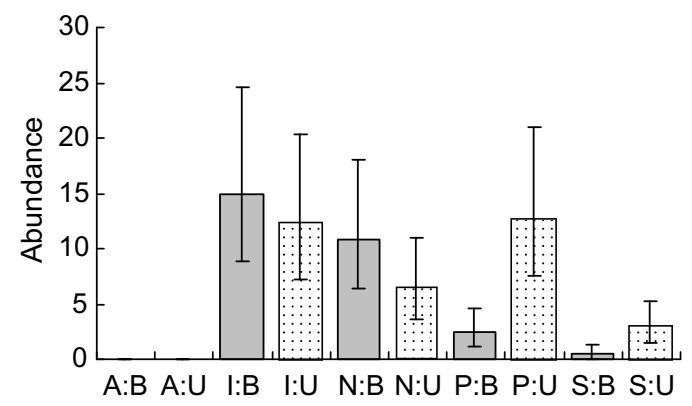

D

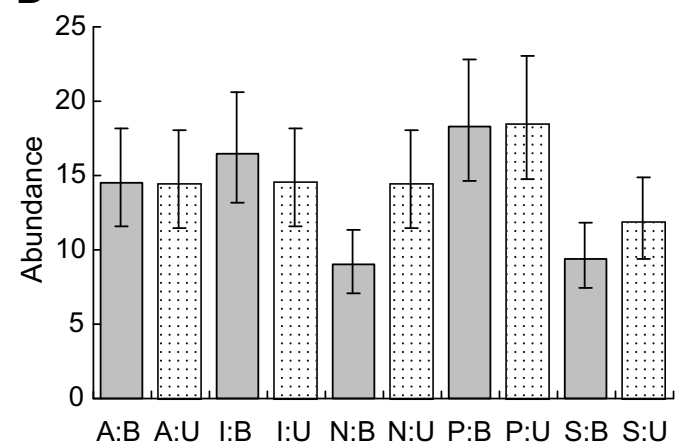

Fig. 4 - The number of species, and the mean abundance of three lizard species showed an interaction between burn treatment and location. The first letter of each code on the $x$-axis indicates location: A: Hambidge; I: Hincks; N: Heggaton North; P: Pinkawillinie; S: Heggaton South. The second letter of each pair indicates burn treatment: $B=b u r n t, ~ U=$ unburnt. Error bars are $95 \%$ confidence limits. Stippling indicates unburnt sites, grey indicates burnt sites. 
skink Lerista dorsalis (Fig. 4C) was significantly more abundant in unburnt sites at Heggaton South, and showed a similar trend towards higher abundance in unburnt sites at Hambidge and Hincks, but equal abundance at Heggaton North. The total number of species also had a location by burn interaction, with fewer species in burnt sites at Heggaton North and South (Fig. 4D).
Nine species did not show a significant response to fire (Fig. 5, Table 2). Six of those species show no apparent differences between burn treatments (Aprasia inaurita, Diplodactylus granariensis, Lerista distinguenda, Lerista edwardsae, Morethia obscura, Pogona sp., Fig. 5A-F). However, three other species show non-significant trends that are noteworthy because they are in the direction predicted by the succession model.
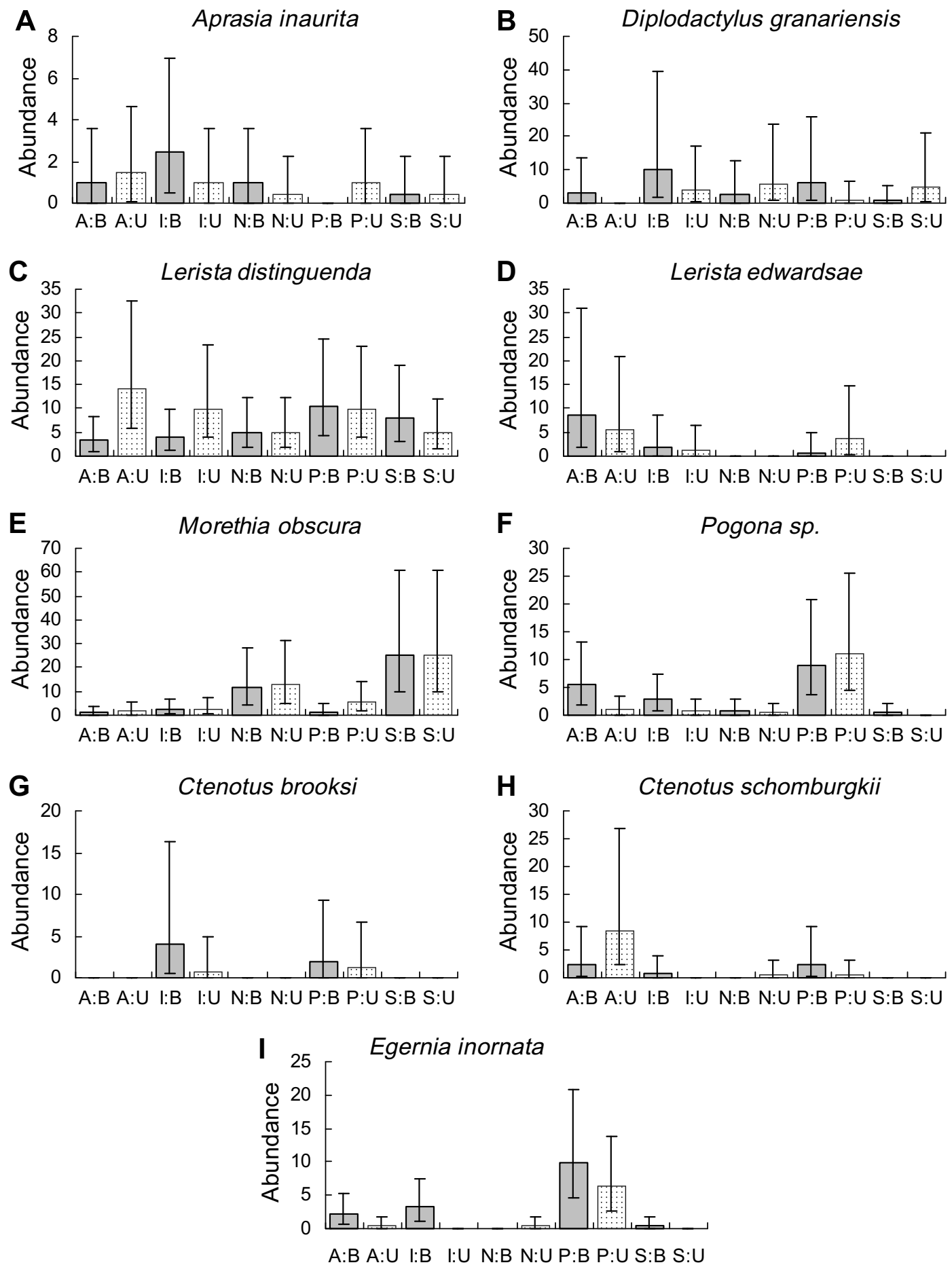

Fig. 5 - Nine species did not show a significant response to fire treatment although trends in mean abundance were evident in three species (G-I). Location and treatment codes as for Fig. 4. Error bars are $95 \%$ confidence limits. Stippling indicates unburnt sites, grey indicates burnt sites. 
Ctenotus brooksi was present at only two locations, and tended to be captured more frequently in burnt sites (Fig. 5G). Ctenotus schomburgkii was only abundant at Hambidge, where there was a tendency to be more abundant in unburnt habitat (Fig. 5H). Egernia inornata showed a trend towards higher abundance in burnt sites at four of the five locations (Fig. 5I).

Thirteen species varied significantly by location (Figs. 4-6, Table 2), and nine of those showed a significant location main effect without interaction (though interactions are displayed in Fig. 5 for some). Two species were absent from Pinkawillinie (Amphibolurus norrisi, Ctenotus atlas, Fig. 4A and C), while one species was only captured at Pinkawillinie (Diplodactylus damaeus, Fig. $3 \mathrm{C}$ ) and one species was most abundant at that location (Egernia inornata, Fig. 5I). Ctenotus atlas (Fig. 4B), Ctenophorus fordi (Fig. 6A) and Ctenotus brooksi (Fig. 5G) were absent from Hambidge, whereas Hambidge was the only location with large numbers of Ctenotus schomburgkii (Fig. 5H,) and Lerista edwardsae (Fig. 5D). Eight species were rare or absent from Heggaton North and South (Ctenophorus cristatus, Fig. 6B; Nephrurus stellatus Fig. 6C; Pogona sp. Fig. 5F; Lerista edwardsae Fig. 5D; Ctenotus brooksi Fig. 5G; Ctenotus schomburgkii Fig. 5H; Egernia inornata Fig. 5I; Ctenophorus fordi Fig. 6A). In contrast, Morethia obscura was most abundant at Heggaton North and South (Fig. 5E). Heggaton North and South and Hambidge had significantly fewer reptiles overall (Fig. 6D).

Multidimensional scaling shows that the reptile community is most strongly affected by location (ANOSIM $R=0.61$, $P<0.001$ ), but within locations, there is weak divergence between burnt and unburnt habitat (ANOSIM $R=0.03, P=0.06$, Fig. 7).
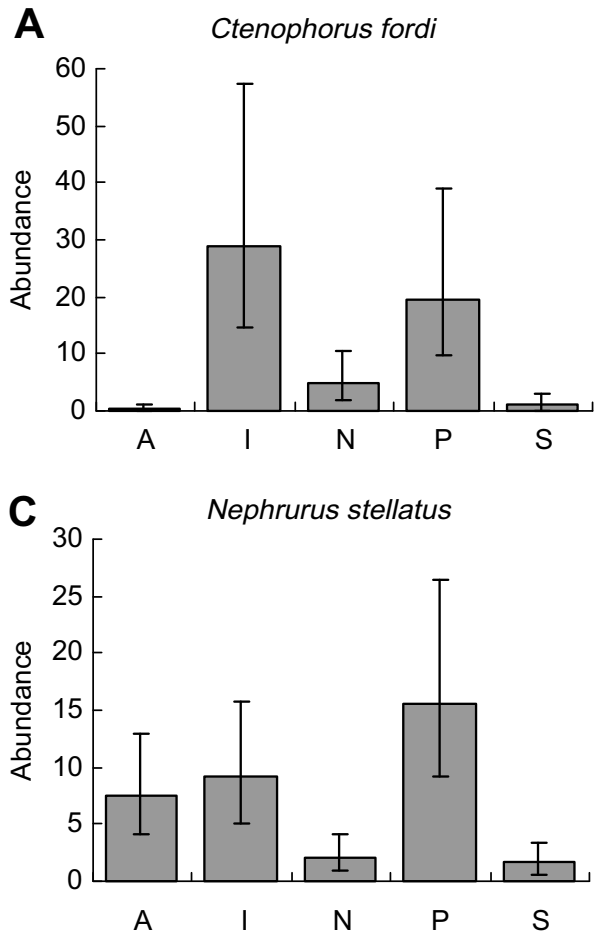

Although very limited information is available for most species, it was possible to classify 14 of the 16 common species into one of the three response groups (Fig. 1) because they are either primarily burrowing species, are dependent on spi-

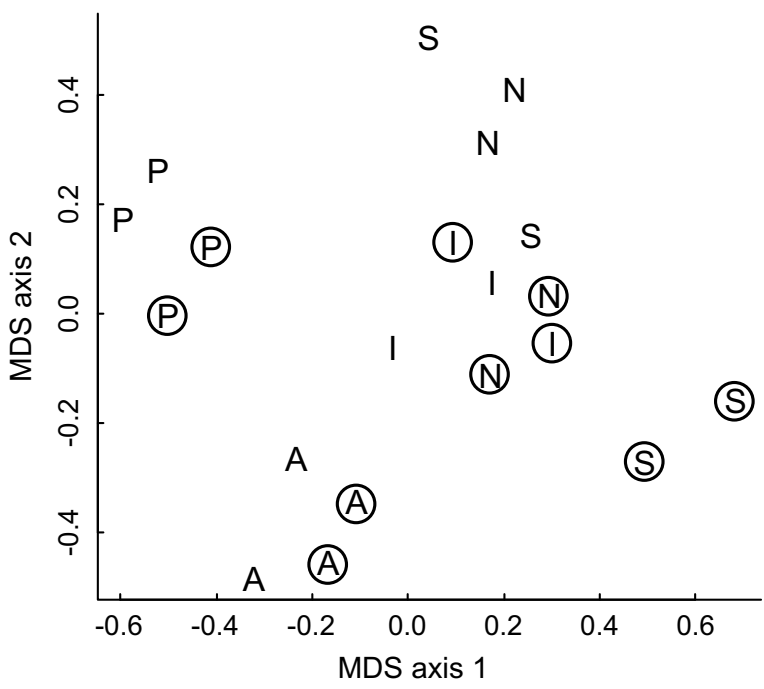

Fig. 7 - Two-dimensional non-metric multi-dimensional scaling of reptile presence/absence, based on a Bray-Curtis distance matrix. Stress $=\mathbf{0 . 1 6 6}$. Circled letters indicate recently burnt sites, un-circled letters are long-unburnt sites. A: Hambidge; I: Hincks; N: Heggaton North; P: Pinkawillinie; S: Heggaton South.
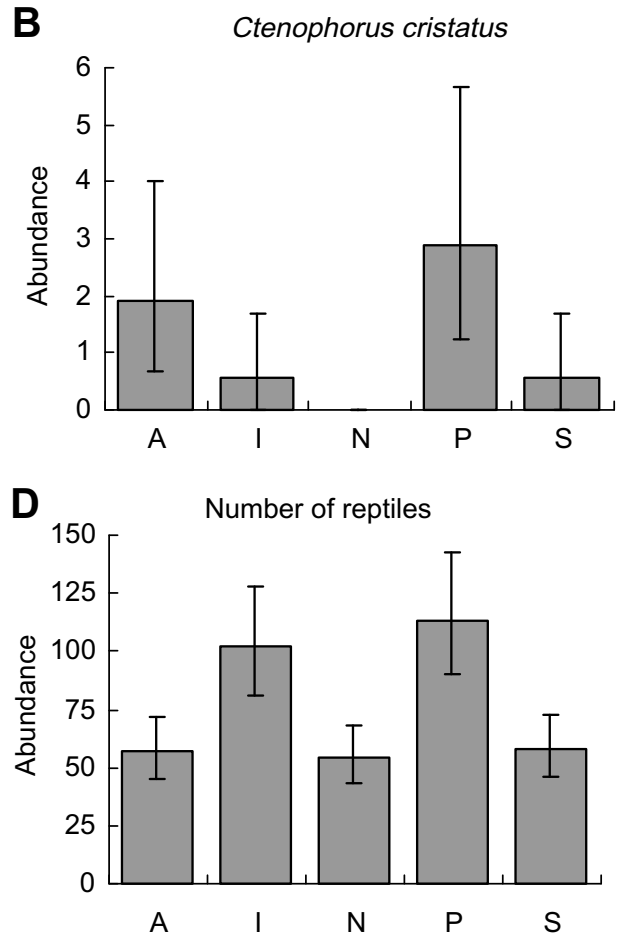

Fig. 6 - Mean abundance of seven reptile species (three shown here, remainder in Fig. 5) and total number of reptiles varied significantly among locations, without an interaction with burn treatment. A: Hambidge; I: Hincks; N: Heggaton North; P: Pinkawillinie; S: Heggaton South. Error bars indicate 95\% confidence limits. 


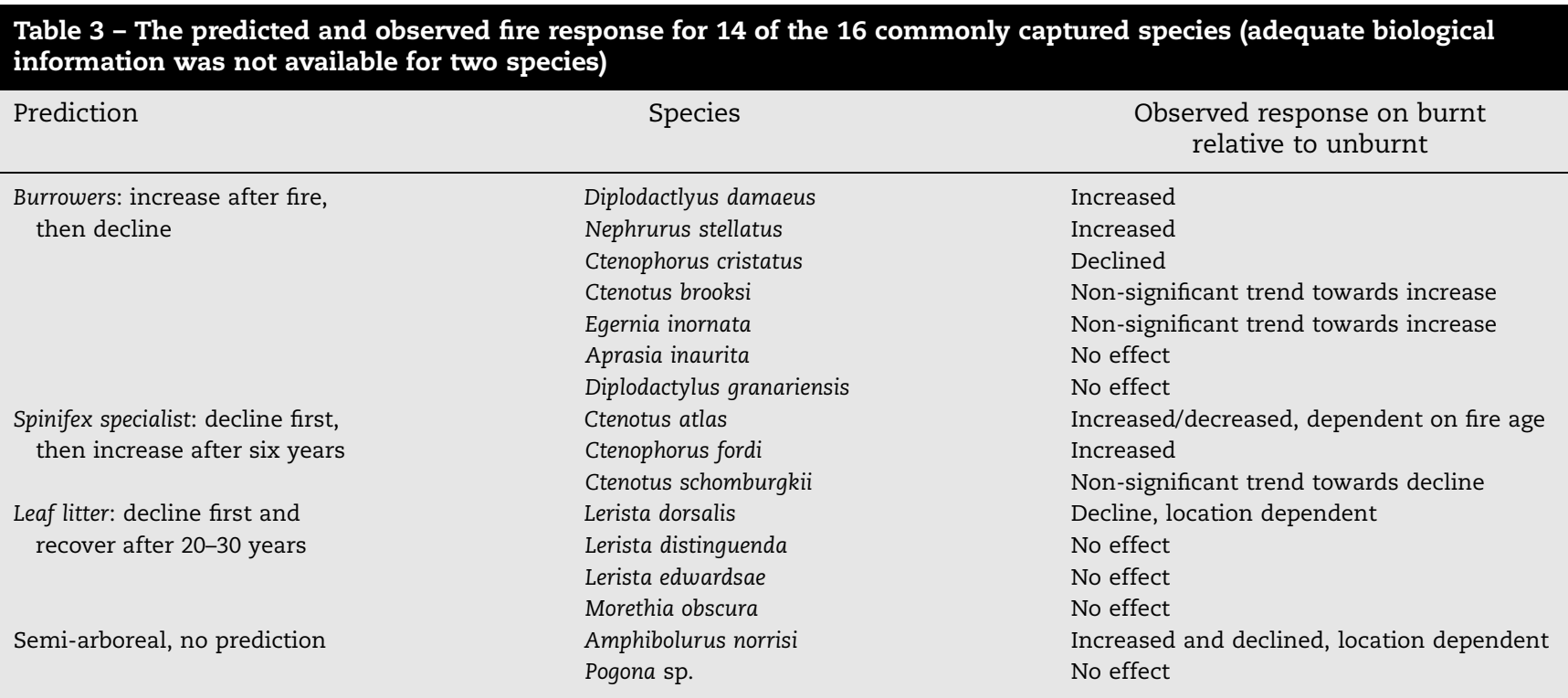

Predictions were based on their use of habitat following Caughley's (1985) classification (Caughley, 1985; Greer, 1989; Woinarski, 1989; pers. comm. Mark Hutchinson, South Australian Museum for D. granariensis and A. norrisi; pers. obs. for A. inaurita).

nifex, or mostly occur in leaf litter (Table 3). However, based on the ANOVA results, only three of the observed responses were significant and consistent with the predictions, and a further four species showed non-significant trends that were largely consistent with the expected response (Table 3). Of seven burrowing species, two geckos (Nephrurus stellatus and Diplodactlyus damaeus) increased after fire and two skinks (Ctenotus brooksi and Egernia inornata) showed non-significant trends towards being more abundant in recently burnt sites, which was the predicted direction. In contrast, the pygopod Aprasia inaurita and the gecko Diplodactylus granariensis showed no response, and Ctenophorus cristatus declined after fire. Three species were classified as spinifex specialists, and Ctenotus atlas showed the predicted response (Figs. 1B and 4B, Table 3) while Ctenotus schomburgkii, showed a trend consistent with the spinifex model (low abundance in very recently burnt site Fig. $5 \mathrm{H}$ ), although it was only abundant at one location and so the pattern was also consistent with the leaf-litter specialist response (Fig. 1C). The third spinifex specialist, Ctenophorus fordi, showed a response expected by burrowing species (Table 3). Three of four species that were expected to be common in leaf litter did not show a significant response to the burn treatment (Table 3). The fourth species, Lerista dorsalis, had a significant burn by location interaction and showed approximately the expected response, although the trend was weak at some locations (Fig. 4C). Although no prediction was available for Amphibolurus norrisi, the response of this species did not fit any of the predicted fire-responses (Table 3).

\section{Discussion}

\subsection{Succession model}

Caughley's (1985) succession model provided accurate predictions for three of the 16 common reptile species. Non-significant trends in four other species were also consistent with the model predictions, although the response of some species was weakly or not expressed at some locations. The threetiered habitat accommodation model (Fox, 1982; Caughley, 1985) (Fig. 1) may therefore identify the mechanism underlying observed fire responses for three to seven of the $16 \mathrm{com}$ mon reptile species. However, eight species did not respond as predicted, and these highlight inadequacies in the current succession model. For example, although Ctenophorus cristatus is a burrowing species (Greer 1989), it also shelters in fallen logs and branches (Houston and Hutchinson, 1998). Fallen branches are likely to accumulate later in the post-fire succession, which may account for the lower abundance of this species in burnt sites. It may therefore be appropriate to recognize a new tier in the fire response model; the accumulation of fallen logs and branches, possibly following a similar curve to the accumulation of leaf litter (Fig. 1C).

Six of the 16 common species showed no response to the burn treatment and occurred in all stages of post-fire habitat succession. This implies that their use of habitat has not been adequately defined because predicted responses based on current knowledge of their habitat use were incorrect. To improve the succession model, at least one additional mechanism should be added to account for species that show no response to fire. Presumably this will involve use of underground shelter to survive the fire, and either the flexibility to exploit resources available at different stages after a fire (e.g. fewer termites, more spiders immediately after fire; Pianka 1996), or specialization to use resources that are independent of time since fire.

The interaction of burn and location shown by Amphibolurus norrisi does not correspond with the interaction expected under the spinifex specialist model (which was shown by Ctenotus atlas). Higher abundance in unburned areas was observed at Heggaton North and Heggaton South, implying that the mechanism driving the interaction is something that varies at a location-wide scale. There are likely to be many things that differ between locations, including different 
competitors, different predators, and different abiotic conditions, so a specific mechanism cannot be identified. However, this interaction demands recognition of a more complex succession model than has been discussed to date. Rather than a predictable turnover of species with time since fire (Letnic et al., 2004), the turnover is dependent on some location-level factor, making the model two-dimensional (time plus factor), not one dimensional (time only). Interactive effects of herbivore grazing and fire on plants have previously been reported (Bailey and Whitham, 2002; Vandvik et al., 2005), but we are unaware of other interactive effects with fire for vertebrates. Detailed life-history research is needed to identify the processes interacting with fire and A. norrisi.

The presumed spinifex specialist Ctenophorus fordi showed the response that was expected for burrowing species, not spinifex specialists. Ctenophorus fordi may not be dependent on spinifex in the study region (Houston and Hutchinson, 1998). Furthermore, C. fordi are capable of digging burrows for nests, and of burying themselves to escape harsh surface conditions (Cogger, 1974), so a burrowing species model is more appropriate.

\subsection{Differences among locations}

Considering the entire reptile community, differences between locations had a larger influence than burn treatment. Although speculative, there are likely to be several factors that have contributed to location level effects, including species ranges that do not overlap all locations (e.g. Lerista dorsalis, Amphibolurus norrisi), interspecific interactions (e.g. higher abundance of Lerista edwardsae, Ctenotus schomburgkii at Hambidge in the absence of Ctenotus atlas and Ctenophorus fordi), different soil (sand much deeper at Hincks and Pinkawillinie compared with Hambidge), different climate (Pinkawillinie further north) or different plant species.

The plant communities at our study sites showed similar location level multidimensional scaling patterns to the reptiles (Henderson and Driscoll unpublished data), where Hambidge and Pinkawillinie were each distinct clusters while Heggaton North, Heggaton South and Hincks formed a third cluster (Fig. 7). This correlation suggests that habitat differences, either plant species or correlated abiotic parameters, should be among the first aspects examined to explore the location effects. A possible approach is to discover regions within one location that are abiotically more similar to the sampled regions of other locations then compare the flora and faunas.

Among reptiles, only the skink Morethia obscura was more abundant at both Heggaton locations, all other species were less abundant or absent. The Heggaton locations were floristically similar to Hincks, but Hincks did not show the same pattern of reduced reptile abundance or high Morethia obscura abundance. Heggaton was the smallest of the locations (Fig. 2), raising the possibility that reduced species richness may be a product of higher extinction rates on this smaller habitat island (MacArthur and Wilson, 1967). If correct, declines from reserves of this size $\left(65 \mathrm{~km}^{2}\right)$ would substantially contradict earlier claims that reptiles are likely to survive in small remnants (Kitchener et al., 1980; Hadden and Westbrooke, 1996). Research addressing the species-area relationship in this system is warranted, in addition to work addressing the other hypotheses we have raised to explain the major location-level differences among reptile communities.

\subsection{Vulnerable fire specialists?}

The results imply that one-third to one half of common reptile species will not have an altered risk of extinction in small fragments due to fire incidence because they appear to be equally abundant in both fire age classes. However, three species were significantly more abundant in recently burnt sites and two additional species showed non-significant trends in the same direction. Two species were less abundant in recently burnt sites, one species showed a non-significant trend towards decline, and two species showed both declines and increases, depending on location or age of the fire. All ten of these species may reach low population density after fire, or after a long period of fire suppression, which could increase their risk of local extinction. Half to two-thirds of the common reptile species may have higher susceptibility to deterministic extinction in remnant vegetation where fire is suppressed for tens of years, and then a single fire burns the entire remnant.

There remain three important caveats to this conclusion. Firstly, we have not assessed absolute population size, so even though abundance may drop after a certain time since fire, the actual risk of extinction may not be substantially altered. Pianka (1996) suggested that early fire specialists can survive at very low densities in long unburnt habitat and Greenberg (2000) reported that sand-hill reptiles that prefer recently burnt habitat may survive in long-unburnt scrub by using occasional shrub-free patches. An ability to survive at low levels during unfavorable periods is similar to Chesson's (2000) storage effect of competitive coexistence. Whether or not reptiles survive through a storage effect remains an important question to answer.

A second caveat is that we have not examined population numbers in the first or second year after fire. The succession model (Fig. 1) predicted that numbers of spinifex specialists and leaf-litter dependent species should drop to near zero in those first years and that would be the time of greatest extinction risk. Estimates of abundance in the first and second years after fire are needed to better understand extinction risk.

The third note of caution relates to possible trap biases in recently burnt and long unburnt habitat. Animals fall into pitfall traps at a rate proportional to their movement, so if movement rates differ between burnt and unburnt habitat, differences in capture rate may reflect differences in activity and not density. One study examining this problem was conducted in an Australian arid environment (Schlesinger, 2007). Schlesinger (2007) found that reptile capture rates were similar in enclosed plots with different grass cover, so to date there is no evidence of strong biases. However, the assumption that the rate of capture is the same in burnt and unburnt habitat remains untested.

\section{Conclusions}

The response of reptiles to fire follows a more complex successional process than previously recognized (Mushinsky, 1985, 1992; Greenberg et al., 1994; Taylor and Fox, 2001a, b; 
Letnic et al., 2004). Reptiles showed linear responses consistent with four processes, including the creation of open habitat after fire, the rapid recovery of a keystone plant species (Mills et al., 1993), the gradual recovery of leaf-litter and recovery of fallen branches. A fifth process, possibly related to burrowing and a generalist diet, enables some species to show a flat response to time since fire. Finally, a two-dimensional successional model was needed to explain the interaction of burn treatment and location for one species. These observations emphasize that a deeper understanding of the mechanisms underlying fire responses is needed to predict the outcome of fire regimes and fire mosaics. Nevertheless, habitat-use succession models provide a promising framework for predicting reptile fire responses and warrant ongoing development and testing.

Approximately half to two-thirds of common reptile species are potentially vulnerable to extinction through inappropriate fire regimes in small remnants. However, the actual risk of extinction remains to be discovered, particularly in the first two years after fire. If most species survive at low levels during unfavorable stages of a succession (Pianka, 1996; Chesson, 2000), then the fire suppression/incineration cycle may not be as serious a threat as it could be given the results of this study.

Although gaps in knowledge remain, management of small remnants for fire specialist species will probably help reduce the risk of local extinction, raising the likelihood that habitat mosaics are a desired management strategy. However, effectively implementing fire mosaics may not be as simple as burning different patches within remnants at different times (Boughton and Malvadkar, 2002; Parr and Andersen, 2006; Wimberly, 2006; Driscoll, 2007). Understanding how to implement effective mosaics (Bradstock et al. 2005, 2006) and application of fire management as an experiment (Walters and Green, 1997) is now critical.

\section{Acknowledgements}

The field work for this project was intense and help from the following people was essential: Adam Aitken, Zonnetje Auburn, Mark Barrett, Kieren Beaumont, Catherine Brown, Aaron Camerons, Bianca Cirjak, Melissa Cundy, Simone Dalgairns, Sarah Davidson, Denise Donoso, Brigid Duns, Martin Emhjellen, Thomas Fallon, Toby Galligan, Karl Gardner, Bruce Gotch, Tamara Green, Renee Gross, Mark Hassam, Bok Ho, Leanne Lawrence, Wayne Lawrence, Christopher Lawson, Angela McGuire, Brendon Meulders, Robyn Morcom, Andrew Murphy, Phillip Northeast, Paula Peeters, Andrew Plimer, Alice Quarmby, Adam Schutz, Anna Seidel, Ian Sellar, Annabel Smith, Ingrid Sternieman, Brooke Swaffer, Andrew Temple, Nicole Whiteside. Joe Tilley, Christine Arnold and Kate Thorn provided essential resources for field work and assisted in the field. Ian Sellar coordinated field work in the second year. The project was funded by the Department for Environment and Heritage, South Australia, Flinders University and the Australia and Pacific Science Foundation. Animals were handled under permit E194 of the Flinders University Animal Welfare committee, and DEH SA permit to undertake scientific research Q24788.

\section{R E F E R E N C E S}

Andersen, A.N., 1991. Responses of Ground-Foraging Ant Communities to 3 Experimental Fire Regimes in a Savanna Forest of Tropical Australia. Biotropica 23, 575-585.

Australian Native Vegetation Assessment, 2001. Australian native vegetation assessment. National Land and Water Resources Audit and Commonwealth of Australia, Canberra, Australia.

Bailey, J.K., Whitham, T.G., 2002. Interactions among fire, aspen, and elk affect insect diversity: reversal of a community response. Ecology 83, 1701-1712.

Bamford, M.J., Roberts, J.D., 2003. The impact of fire on frogs and reptiles in south-west Western Australia. In: Abbott, I., Burrows, N. (Eds.), Fire in ecosystems of south-west Western Australia. Backhuys, Leiden, The Netherlands, pp. 350-361.

Boughton, D., Malvadkar, U., 2002. Extinction risk in successional landscapes subject to catastrophic disturbances. Conservation Ecology 6, (online) URL:/http://www.consecol.org/vol6/iss2/ art2 $\rangle$.

Bradstock, R.A., Bedward, M., Cohn, J.S., 2006. The modelled effects of differing fire management strategies on the conifer Callitris verrucosa within semi-arid mallee vegetation in Australia. Journal of Applied Ecology 43, 281-292.

Bradstock, R.A., Bedward, M., Gill, A.M., Cohn, J.S., 2005. Which mosaic? A landscape ecological approach for evaluating interactions between fire regimes, habitat and animals. Wildlife Research 32, 409-423.

Bradstock, R.A., Cohn, J.S., 2002. Fire regimes and biodiversity in semi-arid mallee ecosystems. In: Bradstock, R.A., Williams, J.E., Gill, A.M. (Eds.), Flammable Australia: the fire regimes and biodiversity of a continent. Cambridge University Press, Cambridge, UK, pp. 238-258.

Bury, R.B., 2004. Wildfire, fuel reduction, and herpetofaunas across diverse landscape mosaics in northwestern forests. Conservation Biology 18, 968-975.

Caughley, J., 1985. Effect of fire on the reptile fauna of mallee. In: Grigg, G., Shine, R., Ehmann, H. (Eds.), Biology of Australasian frogs and reptiles. Royal Zoological Society of NSW and Surrey Beatty \& Sons, Chipping Norton, NSW, pp. 31-34.

Cavitt, J.F., 2000. Fire and a tallgrass prairie reptile community: Effects on relative abundance and seasonal activity. Journal of Herpetology 34, 12-20.

Chesson, P., 2000. General theory of competitive coexistence in spatially-varying environments. Theoretical Population Biology 58, 211-237.

Clarke, K.R., 1993. Nonparametric multivariate analyses of changes in community structure. Australian Journal of Ecology 18, 117-143.

Cogger, H.G., 1974. Thermal relations of the Mallee Dragon Amphibolurus fordi (Lacertilia: Agamidae). Australian Journal of Zoology 22, 319-339.

Cogger, H.G., 1984. Reptiles in the Australian Arid Zone. In: Cogger, H.G., Cameron, E.E. (Eds.), Arid Australia. Surrey Beatty \& Sons, Chipping Norton, N.S.W, pp. 235-252.

Driscoll, D.A., 2004. Extinction and outbreaks accompany fragmentation of a reptile community. Ecological Applications 14, 220-240.

Driscoll, D.A., 2007. The diverse impacts of grazing, fire and weeds. How ecological theory can inform conservation management. In: Lindenmayer, D., Hobbs, R.J. (Eds.), Managing and designing landscapes for conservation: moving from perspectives to principles. Blackwells, Melbourne, pp. 111-130.

Fischer, M., Stocklin, J., 1997. Local extinctions of plants in remnants of extensively used calcareous grasslands 1950-1985. Conservation Biology 11, 727-737. 
Fox, B.J., 1982. Fire and mammalian secondary succession in an Australian coastal heath. Ecology 63, 1332-1341.

Fox, B.J., Taylor, J.E., Thompson, P.T., 2003. Experimental manipulation of habitat structure: a retrogression of the small mammal succession. Journal of Animal Ecology 72, 927-940.

Friend, G., Wayne, A., 2003. Relationships between mammals and fire in south-west Western Australian ecosystems: what we know and what we need to know. In: Abbott, I., Burrows, N. (Eds.), Fire in ecosystems of south-west Western Australia. Backhuys, Leiden, The Netherlands, pp. 363-380.

Gandhi, K.J.K., Spence, J.R., Langor, D.W., Morgantini, L.E., 2001. Fire residuals as habitat reserves for epigaeic beetles (Coleoptera: Carabidae and Staphylinidae). Biological Conservation 102, 131-141.

Gibb, H., Hochuli, D.F., 2002. Habitat fragmentation in an urban environment: large and small fragments support different arthropod assemblages. Biological Conservation 106, 91-100.

Greenberg, C.H., 2000. Fire, habitat structure and herpetofauna in the southeast. In: Ford, W.M., Russell, K.R., Moorman, C.E. (Eds.), The role of fire in nongame wildlife management and community restoration: traditional uses and new directions. General Technical Report NE-GTR-288. U.S. Forest Service, Newton Square, Pennsylvania, pp. 91-99.

Greenberg, C.H., Neary, D.G., Harris, L.D., 1994. Effect of HighIntensity Wildfire and Silvicultural Treatments on Reptile Communities in Sand-Pine Scrub. Conservation Biology 8, 1047-1057.

Greer, A.E., 1989. The biology and evolution of Australian lizards. Surrey Beatty \& Sons, Chipping Norton NSW.

Hadden, S.A., Westbrooke, M.E., 1996. Habitat relationships of the herpetofauna of remnant buloke woodlands of the Wimmera Plains, Victoria. Wildlife Research 23, 363-372.

Hobbs, R.J., 2003. How fire regimes interact with other forms of ecosystem disturbance and modification. In: Abbott, I., Burrows, N. (Eds.), Fire in ecosystems of south-west Western Australia. Backhuys, Leiden, The Netherlands, pp. 421-436.

Houston, T., Hutchinson, M., 1998. Dragon Lizards and Goannas of South Australia. South Australian Museum, Adelaide, Australia.

James, C., 2003. Response of vertebrates to fenceline contrasts in grazing intensity in semi-arid woodlands of eastern Australia. Austral Ecology 28, 137-151.

James, C.D., 1991. Annual variation in reproductive cycles of scincid lizards (Ctenotus) in central Australia. Copeia 1991, 744-760.

Kitchener, D.J., Chapman, A., Dell, J., Muir, B.G., Palmer, M., 1980. Lizard assemblage and reserve size and structure in the Western Australian wheatbelt - some implications for conservation. Biological Conservation 17, 25-62.

Kolb, A., Diekmann, M., 2005. Effects of life-history traits on responses of plant species to forest fragmentation. Conservation Biology 19, 929-938.

Letnic, M., Dickman, C.R., Tischler, M.K., Tamayo, B., Beh, C.L., 2004. The responses of small mammals and lizards to post-fire succession and rainfall in arid Australia. Journal of Arid Environments 59, 85-114.

MacArthur, R.H., Wilson, E.O., 1967. The Theory of Island Biogeography. Princeton University Press, Princeton.

Mills, L.S., Soulé, M.E., Doak, D.F., 1993. The keystone species concept in ecology and conservation. Bioscience 43, 219-224.

Mushinsky, H.R., 1985. Fire and the florida sandhills herpetofaunal community with special attention to responses of Cnemidophorus sexlineatus. Herpetologica 41, 333-342.

Mushinsky, H.R., 1992. Natural History and abundance of southeastern five-lined skinks, Eumerces inexpectatus, on a periodically burned sandhill in Florida. Herpetologica 48, 307-312.
Oksanen, J., Kindt, R., Legendre, P., O’Hara, R.B., 2006. Vegan: Community Ecology Package version 1.6-10 〈http://cran. r-project.org $\rangle$.

Parr, C.L., Andersen, A.N., 2006. Patch mosaic burning for biodiversity conservation: a critique of the pyrodiversity paradigm. Conservation Biology 20, 1610-1619.

Parr, C.L., Chown, S.L., 2003. Burning issues for conservation: a critique of faunal fire research in Southern Africa. Austral Ecology 28, 384-395.

Pianka, E.R., 1996. Long-term changes in the lizard assemblages in the Great Victoria Desert. In: Cody, M.L., Smallwood, J.A. (Eds.), Long-term studies of vertebrate communities. Academic Press, San Diego, California, pp. 191-216.

Quinn, G.P., Keough, M.J., 2002. Experimental design and data analysis for biologists. Cambridge University Press, Cambridge, UK.

R Development Core Team, 2004. R: A language and environment for statistical computing. R Foundation for Statistical Computing, URL/http://www.R-project.org/., Vienna, Austria.

Rice, B., Westoby, M., 1999. Regeneration after fire in Triodia R. Br. Australian Journal of Ecology 24, 563-572.

Robinson, A.C., Heard, L.M.B., 1985. National Parks. In: Twidale, C.R., Tyler, M.J., Davies, M. (Eds.), Natural history of Eyre Peninsula. Royal Society of South Australia, Adelaide, SA, pp. 201-223.

Schlesinger, C.A., 2007. Does vegetation cover affect the rate of capture of ground-active lizards in pitfall traps? Wildlife Research 34, 359-365.

Schlesinger, C.A., Noble, J.C., Weir, T., 1997. Fire studies in mallee (Eucalyptus spp.) communities of western New South Wales: reptile and beetle populations in sites of differing fire history. Rangelands Journal 19, 190-205.

Schwerdtfeger, P., 1985. Climate. In: Twidale, C.R., Tyler, M.J., Davies, M. (Eds.), Natural History of Eyre Peninsula. Royal Society of South Australia, Adelaide, SA, pp. 89-104.

Specht, R.L., 1971. The Vegetation of South Australia. VCH, Adelaide, SA.

State of the Environment Report, 2003. State of the Environment Report. Supplementary report. Government of South Australia, Adelaide, SA.

Taylor, J.E., Fox, B.J., 2001a. Disturbance effects from fire and mining produce different lizard communities in eastern Australian forests. Austral Ecology 26, 193-204.

Taylor, J.E., Fox, B.J., 2001b. Assessing the disturbance impact on vegetation and lizard communities of fluoride pollution interacting with fire and mining in eastern Australia. Austral Ecology 26, 321-337.

Trainor, C.R., Woinarski, J.C.Z., 1994. Responses of lizards to three experimental fires in the savanna forests of Kakadu National Park. Wildlife Research 21, 131-148.

Twidale, C.R., Campbell, E.M., 1985. The form of the land surface. In: Twidal e, C.R., Tyler, M.J., Davies, M. (Eds.), Natural History of Eyre Peninsula. Royal Society of South Australia, Adelaide SA.

Vandvik, V., Heegaard, E., Maren, I.E., Aarrestad, P.A., 2005. Managing heterogeneity: the importance of grazing and environmental variation on post-fire succession in heathlands. Journal of Applied Ecology 42, 139-149.

Venables, W.N., Ripley, B.D., 2002. Modern Applied Statistics with S, Fourth ed. Springer, New York.

Walters, C.J., Green, R., 1997. Valuation of experimental management options for ecological systems. Journal of Wildlife Management 61, 987-1006.

Whelan, R.J., Rodgerson, L., Dickman, C.R., Sutherland, E.F., 2002. Critical life cycles of plants and animals: developing a processbased understanding of population changes in fire-prone landscapes. In: Bradstock, R.A., Williams, J.E., Gill, A.M. (Eds.), Flammable Australia: the fire regimes and biodiversity of a 
continent. Cambridge University Press, Cambridge, UK, pp. 94-124.

Wimberly, M.C., 2006. Species dynamics in disturbed landscapes: When does a shifting habitat mosaic enhance connectivity? Landscape Ecology 21, 35-46.

Woinarski, J.C.Z., 1989. The Vertebrate Fauna of Broombush Melaleuca-uncinata Vegetation in Northwestern Victoria, with
Reference to Effects of Broombush Harvesting. Australian Wildlife Research 16, 217-238.

Woinarski, J.C.Z., Risler, J., Kean, L., 2004. Response of vegetation and vertebrate fauna to 23 years of fire exclusion in a tropical Eucalyptus open forest, Northern Territory, Australia. Austral Ecology 29, 156-176. 